\title{
British BSE inquiry examines scientific involvement
}

The way that government agencies in Britain seek and respond to external scientific advice is expected to be a key theme to emerge from a public inquiry into the origins and handling of the crisis over Bovine Spongiform Encephalitis (BSE) in British cattle.

The inquiry was announced by agriculture minister Jack Cunningham, shortly before Christmas, and is being held jointly by the Ministry of Agriculture, Food and Fisheries (MAFF) and the Department of Health. Cunningham has said that he wants the inquiry to report by the end of the year.

By persuading ministers from previous Conservative administrations to provide details on political decisions taken as far back as the mid-1970s, the inquiry is expected to throw important light on how BSE originated and how its emergence related to changes in the meat processing industry. But the closest attention is likely to be paid to the way that MAFF tried to play down the BSE threat over many years, both in public and to the academic community-even when faced with scientific evidence that it was spreading rapidly in British herds and was becoming a major threat to public health.

"It was a case of the science being manipulated to fit the economics," says Stephen Dealler, a consultant microbiologist based at Burnley Hospital in Lancashire, who was one of the first to argue that scientific evidence suggested that the BSE threat-and in particular, its possible link to Creutzfeld Jakob Disease (CJD) in humans-was being downplayed by the ministry in the interests of the British beef industry.

The inquiry will be headed by a prominent appeals court judge, Lord Justice Phillips, who has already earned wide respect for his handling of complex cases, including that against those involved in the affairs of the suspect media tycoon Robert Maxwell. Phillips will be supported by a scientific assessor and an assessor experienced in public administration. $\mathrm{He}$ has been asked "to reach conclusions on the adequacy of the response [to BSE and the so-called 'new-variant' CJD (nvCJD)], taking into account the state of knowledge at the time."

One senior scientific adviser emphasizes the sharp contrast between the handling of data in the early 1980s from the AIDS outbreak in the United States and that of the BSE outbreak by MAFF, pointing out that this reflects the different attitude of administrators as much as government rules. In the former case, authorities moved rapidly

permit the Department of Health to be involved," he adds. "But whereas the health department tends to take action on problems, even if it may play these down in public, MAFF not only told everyone that everything was okay, but also refused to act adequately behind the scenes."

Some government critics had hoped that the inquiry would be given a stronger and broader remit. "We would have liked to see a full judicial inquiry with the power to subpoena witnesses, which we think would have been more effective," says Julie Shepherd, senior public affairs officer with the Consumer Association. "We are also worried about the time window. While we are pleased that the inquiry will go back to the 1970 s, we also find it extraordinary that they will not look at anything that happened after March 1996."

The announcement of an inquiry, to involve independent researchers in identifying the problem and suggesting strategies to contain it; in the latter, the ministry maintained tight control not only over the data itself, but also on how it was presented both to the public and to the scientific community.

"We have to find out not only why BSE appeared and spread in the way it did, but why insufficient scientific research was carried out into the problem at the time, and why the academic community did not complain about this more loudly," says Dealler. "One of the problems, for example, was that MAFF was determined to do all the scientific work itself, and did not

\section{Xenotransplantation under FDA spotlight}

Xenotransplantation has once again become an area of high priority for the US Food and Drug Administration (FDA), which has participated in two recent meetings aimed at addressing growing concerns about the technology.

As Nature Medicine went to press, a revision of the US department of Health and Human Services xenotransplantation policy guidelines issued in September 1996 was expected following its discussion at a public forum in Washington on January 22nd. Some researchers hoped that a presentation at the meeting by Fritz Bach- published as a commentary in this issue ( $\mathrm{p}$ 141) and as correspondence in Nature (January 22nd, 1998)-calling for a moratorium on clinical trials of xenotransplantation until ethical aspects of the technology have been addressed, would postpone release of the updated guidelines (see Editorial, p 131).

At an earlier meeting last December, an expert panel of the FDA's Center for Biologics (CBER) subcommittee made its debut, specifically to examine ongoing clinical trials that involve the transplantation of pig organs and tissues. John Logan, 